\title{
POLA PENGOBATAN TUBERKULOSIS PARU DI BALAI BESAR KESEHATAN PARU MASYARAKAT MAKASSAR PERIODE JANUARI - JUNI 2011
}

\author{
Hendra Herman, Bayu Putra, Citra Dana
}

Fakultas Farmasi Universitas Muslim Indonesia

Email : noncee2307@gmail.com

\begin{abstract}
The research was about Tuberculosis Drugs Using System in the Balai Besar Kesehatan Paru Masyarakat Makassar (BBKPM) Period January 2011 - June 2011. The aim of this research was to describe about using system so obtained TBC drugs which used in the Tuberculosis Drugs Using-System in the Balai Besar Kesehatan Paru Masyarakat Makassar (BBKPM) Period January 2011 - June 2011. The data taking prospectly via all the tuberculosis patient medical record in the Tuberculosis Drugs Using System in the Balai Besar Kesehatan Paru Masyarakat Makassar (BBKPM) Period January 2011 - June 2011 obtained 30 patients. The result of this research can be concluded that from the regiment side, about 96,7\% Tuberculosis patients which treatment in the Balai Besar Kesehatan Paru Masyarakat Makassar (BBKPM) Period January 2011 - June 2011 were category 1 and the residual was category 3. While the side of combination with the other drug, giving combination dominated about $96,7 \%$. While if the give single drug about 3,3\%. The frequency of the other drug usage was dextromethorphan about $90 \%$ and the smaller was pyridoxin about $10 \%$.
\end{abstract}

Key Word : Using System, Tuberculosis Drugs, BBKPM

\section{PENDAHULUAN}

Salah satu penyebab kematian utama yang disebabkan oleh infeksi adalah tuberkulosis. Tuberkulosis merupakan penyebab kematian nomor tiga setelah penyakit jantung dan penyakit pernafasan akut pada seluruh kalangan usia. Tuberkulosis adalah penyakit infeksi menular yang disebabkan oleh Mycobacterium tuberkulosis, dimana kuman batang aerobik dan tahan asam ini merupakan organisme pathogen maupun saprofit (Price, 2005).

Penularan penyakit ini sebagian besar melalui inhalasi basil yang mengandung droplet nucleus, khususnya yang terdapat pada pasien Tuberkulosis dengan batuk berdarah atau berdahak yang mengandung bakteri tahan asam (BTA), (Sudoyo, 2001)

Peningkatan jumlah penderita tuberkulosis disebabkan oleh berbagai faktor, yakni kurangnya tingkat kepatuhan penderita untuk 
berobat dan meminum obat,timbulnya resistensi ganda, kurangnya daya tahan hospes terhadap mikobakteria, dan berkurangnya daya bakterisid obat yang ada. Oleh karena itu perlu keterlibatan berbagai pihak dan sektor dalam masyarakat, kalangan swasta, organisasi profesi dan organisasi sosial serta (Lembaga Swadaya Masyarakat) LSM terutama profesi apoteker di apotek, instalasi farmasi rumah sakit maupun tempat lain yang melayani masyarakat dalam memenuhi kebutuhannya akan obat tuberkulosis (Price, 2005).

Balai besar kesehatan paru masyarakat (BBKPM) makassar merupakan Instansi pemerintah yang menangani penyakit tuberkulosis. Pentingnya mengetahui pola pengobatan Tuberkulosis Paru adalah untuk mencegah terjadinya kesalahan pengobatan dan untuk meningkatkan efektivitas pengobatan, diharapkan dengan penelitian ini dapat menjadi masukan bagi pihak-pihak yang terkait demi pembangunan Indonesia yang sehat (Anonim, 2007).

\section{METODE PENELITIAN}

\section{A. Jenis Penelitian}

Penelitian ini merupakan penelitian observasional dengan pengambilan data secara retrospektif melalui kartu rekam medik penderita Tuberkulosis Paru di Balai Besar Kesehatan Paru Masyarakat (BBKPM) Makassar periode Januari - Juni 2011.

\section{B. Waktu dan Tempat Penelitian}

Penelitian ini di lakukan di Balai Besar Kesehatan Paru Masyarakat (BBKPM) Makassar pada bulan Januari 2012.

\section{Populasi dan Sampel}

\section{Populasi}

Pasien yang terdiagnosa Tuberkulosis Paru di Balai Besar Kesehatan Paru Masyarakat (BBKPM) Makassar periode Januari - Juni 2011.

\section{Sampel}

Sampel yang digunakan pasien yang baru terdiagnosa Tuberkulosis Paru di Balai Besar Kesehatan Paru Masyarakat (BBKPM) Makassar periode Januari - Juni 2011.sebanyak 30 orang.

\section{Metode Pengumpulan Data}

Data ditelusuri dari rekam medis, adapun data yang dikumpulkan berupa karakteristik demografi pasien, yaitu usia dan jenis kelamin ,pemberian pengobatan dan penggunaan kombinasi obat lain pada pasien Tuberkulosis Paru di Balai Besar 
Kesehatan Paru Masyarakat (BBKPM) Makassar periode Januari - Juni 2011.

\section{E. Pengolahan dan Analisis Data}

Data yang diperoleh kemudian dianalisis dengan menggunakan metode statistik deksriptif. Data yang sama dikelompokkan, kemudian disajikan dalam bentuk tabel.

\section{HASIL PENELITIAN}

Berdasarkan hasil penelitian di

Balai Besar Kesehatan Paru Masyarakat (BBKPM) Makassar periode Januari - Juni 2011 diperoleh pasien yang berobat dan baru terdiagnosa Tuberkulosis Paru sebanyak 30. Hasil penelitian yang diperoleh disajikan dalam bentuk tabel sebagai berikut :

1. Karakteristik Demografi Pasien

Hasil penelitian berdasarkan Usia dan Jenis Kelamin di Balai Besar Kesehatan Paru Masyarakat (BBKPM) Makassar periode Januari - Juni 2011, terhadap 30 pasien Tuberkulosis dapat dilihat pada tabel 1 berikut ini :

Tabel 1.Distribusi karakteristik Usia dan Jenis Kelamin Pasien Tuberkulosis Paru Di BBKPM Makassar Periode Januari - Juni 2011

\begin{tabular}{|c|c|c|c|}
\hline No. & Karakteristik Demografi & Jumlah ( $n=30)$ & Persentase (100\%) \\
\hline 1. & $\begin{array}{l}\text { Jenis Kelamin } \\
\text { a.Pria } \\
\text { b. Wanita }\end{array}$ & $\begin{array}{c}24 \\
6\end{array}$ & $\begin{array}{l}80 \% \\
20 \%\end{array}$ \\
\hline & $\begin{array}{l}\text { Usia (tahun) } \\
\text { a.Dewasa }(15-49) \\
\text { b. Manula }(>50)\end{array}$ & $\begin{array}{c}23 \\
7\end{array}$ & $\begin{array}{l}76,7 \% \\
23,3 \%\end{array}$ \\
\hline
\end{tabular}

2. Pemberian Pengobatan

Hasil penelitian berdasarkan Pemberian Pengobatan di Balai Besar Kesehatan Paru Masyarakat
(BBKPM) Makassar periode Januari - Juni 2011, terhadap 30 pasien Tuberkulosis dapat dilihat pada tabelpada tabel 2 berikut ini :

Tabel 2. Distribusi Kategori Pengobatan Penderita Tuberkulosis Paru Di BBKPM Periode Januari - Juni 2011

\begin{tabular}{cccc}
\hline No. & Kategori Pengobatan & Jumlah $(\mathbf{n}=\mathbf{3 0})$ & Persentase ( 100 \% ) \\
\hline 1. & Kategori 1 & 29 & $96,7 \%$ \\
2. & Kategori 3 & 1 & $3,3 \%$ \\
\hline
\end{tabular}


3. Kombinasi obat lain

Hasil penelitian berdasarkan

cara penggunaan obatdi Balai

Besar Kesehatan Paru Masyarakat
(BBKPM) Makassar periode Januari - Juni 2011, terhadap 30 pasien Tuberkulosis dapat dilihat pada tabel pada tabel 3 berikut ini :

Tabel 3. Distribusi penggunaan obat anti Tuberkulosis secara tunggal dan kombinasi obat lain dalam pengobatan penderita Tuberkulosis Paru di BBKPM Periode Januari - Juni 2011

\begin{tabular}{cccc}
\hline No. & Pengobatan & Penggunaan & Persentase \\
\hline 1. & Tunggal & 1 & $3,3 \%$ \\
2. & Kombinasi & 29 & $96,7 \%$ \\
\hline
\end{tabular}

Hasil penelitian berdasarkan intensitas dengan kombinasi obat lain di Balai Besar Kesehatan Paru Masyarakat (BBKPM) Makassar periode Januari - Juni 2011, terhadap 30 pasien Tuberkulosis dapat dilihat pada tabel pada tabel 4 berikut ini :

Tabel 4.Distribusi intensitas penggunaan kombinasi obat lain dalam pengobatan penderita Tuberkulosis Paru di BBKPM Periode Januari - Juni 2011

\begin{tabular}{clcc}
\hline No. & \multicolumn{1}{c}{ Obat lain } & Intensitas penggunaan & Persentase \\
\hline 1. & Dextromethorphan & 27 & $90 \%$ \\
2. & Prednisolon & 6 & $20 \%$ \\
3. & Glyceril guaikolat & 21 & $70 \%$ \\
4. & Chlorfenilamin Maleat & 11 & $37 \%$ \\
5. & Vitamin C & 6 & $20 \%$ \\
6. & Vitamin B6 & 3 & $10 \%$ \\
\hline
\end{tabular}

\section{PEMBAHASAN}

Tuberkulosis adalah penyakit infeksi menular yang disebabkan oleh Mycobacterium

tuberkulosis. Mycobacterium

tuberculosis merupakan kuman batang aerobik dan tahan asam dapat merupakan organisme patogen maupun saprofit dimana penularan penyakit ini sebagian besar melalui inhalasi basil yang mengandung droplet nucleus. Penelitian ini menggunakan data-data dari kartu rekam medik penderita tuberkulosis paru di Balai Besar Kesehatan Paru Masyarakat (BBKPM) Makassar periode Januari - Juni 2011, dengan jumlah kasus sebanyak 30 pasien tuberkulosis paru baru di Balai Besar Kesehatan Paru Masyarakat Makassar Periode Januari 2011 - Juni 2011.

Tatacara

pemberian pengobatan bagi penderita penyakit paru di Balai Besar Kesehatan Paru Masyarakat (BBKPM) Makassar 
berdasarkan Depkes RI tahun 2007 Tentang Pedoman Nasional Penanggulangan Tuberkulosis, cetakan ke 10. Obat yang paling sering diresepkan untuk pasien Tuberkolosis Paru itu sendiri adalah Obat Anti Tuberkulosis (OAT) Penggunaan obat-obat tuberkulosis paru di Balai Besar Kesehatan paru telah menggunakan konsep obat-obat standar tuberkulosis yang telah direkomendasikan oleh WHO dan IUATLD (International Union Against Tuberkulosis and Lung Disease).

Pemberian obat di Balai Besar Kesehatan Paru Masyarakat (BBKPM) Makassar berdasarkan berat badan sesuai dengan ketentuan yang tertera pada Depkes 2007 tentang Pedoman Nasional

Penanggulangan Tuberkulosis.

Hasil penelitian pada tabel 5 menunjukkan distribusi karakteristik demografi pasien yakni jenis kelamin dan usia. Pada distribusi jenis kelamin diperoleh data pria sebesar $80 \%$ sedangkan yang wanita sebesar $20 \%$. Untuk distribusi usia, diketahui kategori dewasa (15-49 tahun) sebesar $76,7 \%$, sedangkan kategori manula (>50 tahun) sebesar $23,3 \%$. Karakteristik demografi pasien untuk jenis kelamin tidak menunjukkan keterkaitan yang erat dengan pengobatan Tuberkulosis Paru, akan tetapi pola hidup yang tidak sehat dari Pria seperti minum alkohol danmerokok sangat mempengaruhi pola pengobatan terutama jika pola hidup yang tidak sehat tersebut menyebabkan kegagalan atau kekambuhan pada penderita Tuberkulosis Paru. Sama halnya dengan karakteristik demografi untuk kategori usia. Tidak ada keterkaitan erat terhadap pengobatan Tuberkulosis Paru.

Hasil penelitian pada tabel 6 menunjukkan distribusi pemberian pengobatan penderita Tuberkulosis Paru dimana pada kategori OAT 1 sebesar $96,7 \%$ dan pada kategori OAT 3 sebesar 3,3\%. Kategori OAT 1 ditujukan untuk penderita baru TuberkulosisParu bakteri tahan asam positif, penderita baru Tuberkulosis Paru bakteri tahan asam negatif rontgen positif yang sakit berat serta penderita Tuberkulosis ekstra paru berat. Untuk kategori OAT 3 ditujukan untuk penderita baru BTA negatif rontgen positif sakit ringan dan penderita TB ekstra paru ringan.Pembagian kategori pengobatan dilakukan berdasarkan hasil pemeriksaan dahak secara mikroskopis. Apabila hasil pemeriksaan dahak menunjukkan 
bakteri tahan asam positif, maka pemberian obat diberikan sesuai dengan panduan Obat Anti Tuberkulosis (OAT) yang telah direkomendasikan oleh WHO dan IUTLD (International Union Against Tuberkulosis and Lung Dissease).

Hasil penelitian pada tabel 7 menunjukkan distribusipenggunaan obat anti Tuberkulosis secara tunggal dan kombinasi obat lain dalam pengobatan penderita Tuberkulosis Paru. Tabel ini menunjukkan bahwa $3,3 \%$ penggunaan OAT secara tunggal yaitu hanya HRZE saja sedangkan kombinasi obat lain sebesar 96,7\%. Penggunaan kombinasi obat lain digunakan untuk menekan atau meminimalizir efek samping dari Obat Anti Tuberkulosis ataupun untuk mengobati komplikasi yang ditimbulkan oleh Tuberkulosis Paru seperti Peradangan, Batuk, Dahak, peningkat daya sistem imun, dan lainlain.

Tabel 8 menunjukkan distribusi intensitas penggunaan kombinasi obat lain dalam pengobatan penderita Tuberkulosis Paru. Tabel ini menunjukkan intensitas penggunaan Dextromethorphan sebesar $90 \%$, Prednisolon sebesar 20\%, Glyceril guaikolat sebesar $70 \%$, Chlorfenilamin Maleat sebesar 37\%,
Vitamin C sebesar $20 \%$ dan Vitamin B6 sebesar 10\%. Dari data yang diperoleh, penggunaan vitamin B6 yang paling rendah, padahal seharusnya intensitas penggunaan dari vitamin B6 ditingkatkan karena B6 dapat menekan efek samping dari Isoniazid yang dapat merusak hati.

Pola pengobatan sangat dipengaruhi olehtingkat kepatuhan penderita untuk berobat dan meminum obat, masa pengobatan yang cukup lama, serta kurangnya daya tahan hospes terhadap mikrobakteri dapat menyebabkan perubahan pola pengobatan Obat Anti Tuberkulosis (OAT) karena disesuaikan dengan kondisi masing-masing penderita.

\section{KESIMPULAN}

Kesimpulan dari penelitian yang dilakukan bahwa dari segi pemberian pengobatan, $96,7 \%$ penderita Tuberkulosis Paru yang berobat di Balai Besar Kesehatan Paru Masyarakat (BBKPM) Makassar periode Januari - Juni 2011 adalah kategori OAT 1 sisanya 3,3\% adalah kategori OAT 3. Sedangkan dari segi kombinasi dengan obat lain, pemberian secara kombinasi mendominasi sebesar96,7\% sedangkan yang tunggal sebesar $3,3 \%$. Frekuensi penggunaan obat lain terbesar adalah Dextromethorphan 
sebesar $90 \%$ dan terkecil adalah vitamin B6 sebesar 10\%.

\section{DAFTAR PUSTAKA}

Anonim, 2007, Sejarah Balai Besar Kesehatan Paru Masyarakat Makassar, available at http://balaiparumakassar.co m/index.php?option(Diakses 12 Januari 2011)

Depkes RI., 2005, Pharmaceutical Care Untuk Penyakit Tuberkulosis, Direktorat Bina Farmasi Komunitas dan Klinik, Direktorat Jenderal Bina Kefarmasian dan Alat Kesehatan, Jakarta. (32-34)

Depkes,RI.,2007, Pedoman Nasional Penanggulangan

Tuberkulosis , Edisi 2, cetakan pertama, Jakarta. (3 $-35)$

Entjang, I, 2003.Mikrobiologi dan parasitology, penerbit PT. Citra Aditya Bakti, Bandung (131).

Gunawan, S., 2007, Farmakologi Dan Terapi, edisi kelima, Fakultas Kedokteran Universitas Indonesia. Jakarta. $(48-49)$
Loksan, G,.2008, Radiologi Toraks Tuberkulosis Paru, CV. Agung Seto Jakarta. $(2-3)$.

Mansjoer,A., 2005. Kapita Selekta Kedokteran,jilid I.,Penerbit Buku Kedokteran EGC,Jakarta (472 - 477)

Price,S,. Wilson,Lorraine M.,2005 , Patofisiologi,Edisi 6, Volume 2.,Penerbit Buku Kedokteran,EGC., Jakarta. $(852-861)$

Radji, M, 2011. Panduan Mahasiswa Farmasi dan Kedokteran, Penerbit buku kedokteran EGC, Jakarta (165 - 173).

Rustiyanto, E, 2009. Etika Profesi Perekam Medis dan Informasi Kesehatan. Graha IImu, Yogyakarta.

Sudoyo A .,2001. Buku Ajar Imu Penyakit Dalam, Penerbit FK UI.Jakarta. ( 2230 2234 )

Yunus, M, 2006. Pedoman Diagnosis dan Penatalaksanaan di Indonesia, perhimpunan Dokter Paru Indonesia, Jakarta (37). 